\title{
BBVA
}

Working Paper, № 15/18

Hong Kong, June 2015

\section{Beyond Minerals: China-Latin American Trans-Pacific Supply Chain}

Alicia Garcia-Herrero

K.C. Fung

Jesus Seade 


\title{
Beyond Minerals: China-Latin American Trans-Pacific Supply Chain
}

\author{
Alicia Garcia-Herrero*, K.C. Fung*, Jesus Seade*
}

\section{Abstract}

In this paper, we highlight three characteristics of China-Latin American economic relations. China-Latin American economic relationships are asymmetric, comparative-advantage driven and motivated by both political and economic considerations. There are several co-operative measures that China and Latin America can focus on. China can be encouraged to invest in not only mining in Latin America, but also in infrastructure and in manufacturing facilities. China and Latin America can deepen their Trans-Pacific production network. Utilizing the advantages of being close to and in the same time zone as the U.S. market, this pan China-Latin America supply chain can be a potent supplier and exporter to the United States.

Keywords: International trade, commodity dependence, supply chains

JEL: F19, F59

\footnotetext{
* Alicia Garcia Herrero (alicia.garcia-herrero@bbva.com) is Chief Economist for Emerging Markets at Banco Bilbao Vizcaya Argentaria (BBVA) since December 2007. She also serves as special advisor to the European Commission on China issues, non-resident Faculty at China-Europe International Business School (CEIBS) in Shanghai, Adjunct Professor at City University of Hong Kong, and as member of the Advisory Board of the Hong Kong Institute of Monetary Research (HKIMR) K.C. Fung is Professor of Economics at the University of California, Santa Cruz. He was a senior economist at the White House Council of Economic Advisers during the George H.W. Bush and Bill Clinton administrations, and served as an academic adviser to the U.S. International Trade Commission (USITC) from 2006 to 2010. In 2011, he testified before a U.S. Congressional Commission on trade and investment of China. Jesus Seade is a Chair Professor of Economics at Lingnan University, Hong Kong. He studied in Mexico and in the U.K. (University of Oxford: B.Phil. and D.Phil. in Economics). He was Professor of Public Economics at Warwick University, where he co-founded and was Director of its Development Economics Research Center. In 1989 he was appointed Mexico's Chief Uruguay Round Trade Negotiator and Ambassador to GATT, whose senior management he joined as Deputy Director-General in 1993. In 1998 he joined the International Monetary Fund where he was Assistant Director for Policy Development and then Senior Advisor for Fiscal Affairs.
} 


\section{Three Characteristics of China-Latin America Economic Links}

In the last decade, the economic relationships between China and Latin America have deepened and intensified. Exports from Latin America to China increased from US\$11 billion in 2003 to close to US\$106 billion in 2013. China is the second largest export market for Latin America as a whole, behind only the United States. Indeed, for Brazil, Uruguay and Chile, China is the largest export market in the world. China also ranks as the second largest export market for Argentina, Colombia, Cuba and Peru. Furthermore, between 2005 and 2013, China committed about US $\$ 98$ billion of loans to Latin America-mostly to Venezuela, Argentina and Brazil (Figure 1).

Figure 1

China's Imports from Latin America by country (US\$ billion)

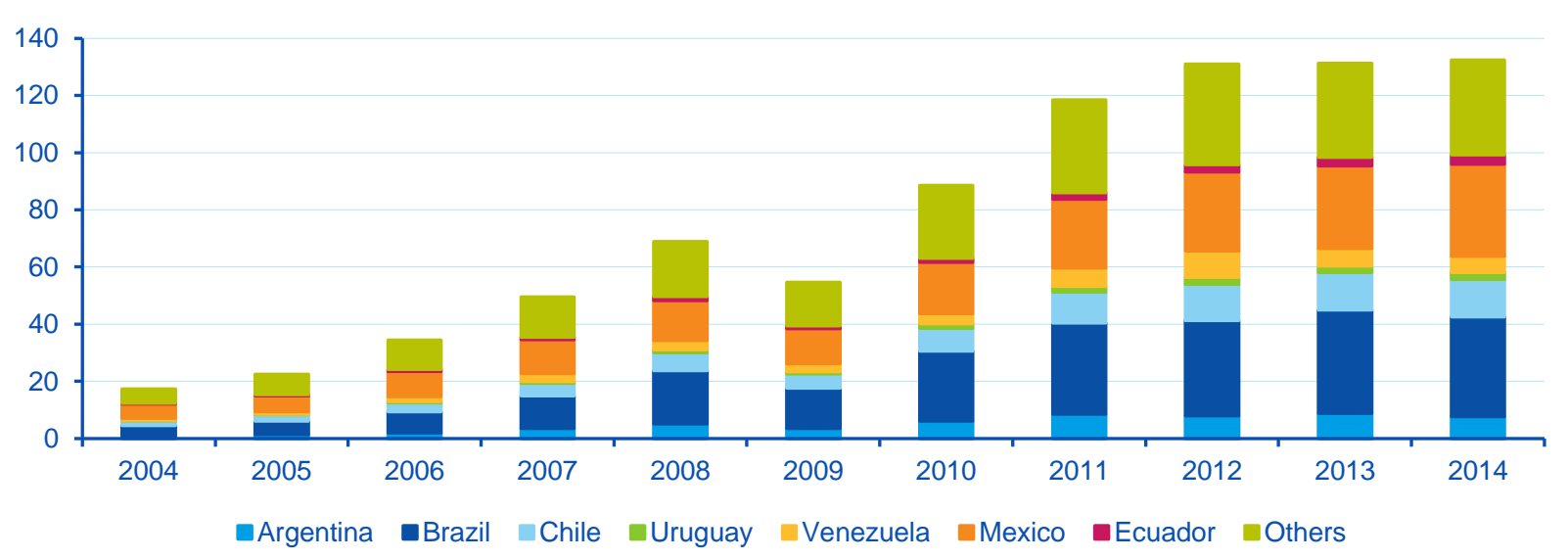

Source: IMF DOT

Latin America consists of many heterogeneous countries. Latin America includes economies as different as Argentina, Bolivia, Brazil, Chile, Columbia, Costa Rica, Cuba, Dominican Republic, Ecuador, Guatemala, Mexico, Panama, Peru, Paraguay, El Salvador, Uruguay and Venezuela (Fung and Alicia Garcia-Herrero 2014). It would be inaccurate to lump so many diverse countries into one entity. Nonetheless, we can distill three features of China-Latin America economic links.

First, the economic relationships can be viewed as asymmetric. Other than Hong Kong, China's top export markets include the United States and Japan. China is also trading more than 1 billion euros per day with the European Union. Latin America is important to China, but it is not among China's most important export markets. As Table 1 shows, China's top export markets include Hong Kong, the United States, EU 28, Japan, South Korea, Russia, Vietnam and India, etc. None of the Latin American countries shows up as the top ten markets. In contrast, as Table 2 shows, China is either the largest or the second largest export market for many Latin American economies, including Brazil, Argentina, Peru and Chile. 
Table 1

China's Top Export Markets, 2013

\begin{tabular}{lc}
\hline Economy & Rank as Export Market \\
\hline Hong Kong & 1 \\
USA & 2 \\
EU 28 & 3 \\
Japan & 4 \\
South Korea & 5 \\
Russia & 6 \\
Vietnam & 7 \\
India & 7 \\
Malaysia & 8 \\
Singapore & 9 \\
\hline
\end{tabular}

Source: European Commission, 2015

Table 2

Importance of China as an Export Market for Various Latin American Countries, 2014

\begin{tabular}{lc}
\hline Country & Rank of China as Export Market \\
\hline Argentina & 2 \\
Brazil & 1 \\
Chile & 1 \\
Columbia & 2 \\
Cuba & 2 \\
Peru & 2 \\
Uruguay & 2 \\
Latin America & 1 \\
\hline
\end{tabular}

Source: Deutsche Bank Research, 2015

Second, the China-Latin America trade relationship can be described as comparative advantage-driven. Chinese exports to Latin America are mostly manufactured products. In exchange, much of the exports from Latin America to China consist of minerals and agricultural products, particularly copper, iron and soy (Figure 2). Only about $8 \%$ of Latin American exports to China are manufactured goods. As an illustration, China is the largest consumer of iron ore in the world. In 2005, Brazil exported 60 million tons of iron ore to China. In 2013, such exports reached 170 million tons.

This pattern of trade can be explained by different endowments. China is labor-abundant while many Latin American economies are well endowed with land, minerals, fuels and water. For example, Latin America is estimated to be endowed with more than $22,000 \mathrm{~m} 3$ of fresh water per capita, more than $0.016 \mathrm{sq}$. km of forests per capita and about $0.013 \mathrm{sq}$. $\mathrm{km}$ of land per person. In contrast, China is estimated to have only less than $3,000 \mathrm{~m} 3$ of fresh water per capita, less than $0.002 \mathrm{sq} \mathrm{km}$ of forests per capita and about $0.004 \mathrm{sq}$ $\mathrm{km}$ of land per person (Estevadeordal, Moreira, Martincus and Blyde 2014).

Third, Chinese loans and investment in the region seem to have political-economic motivations. In Fung and Garcia-Herrero (2012), we ran an augmented gravity model regression equation on the determinants of Chinese foreign direct investment outflows:

$$
\begin{aligned}
\operatorname{In} F D I_{e i t}= & \beta_{1} \ln G D P_{i t}+\beta_{2} \ln P G D P_{i t}+\beta_{3} \ln D_{e i}+\beta_{4} B_{e i}+ \\
& \beta_{5} C r_{i t}+\beta_{6} L W_{i t}+\beta_{7} \ln \left(I M P+E X P_{i t}\right)+\beta_{8} F T A_{e i t}+\beta_{10} K C_{i t}+ \\
& \beta_{11} \ln F S_{i t}+\beta_{12} \ln F u S_{i t}+\beta_{12} \ln O S_{i t}++\beta_{13} \ln R D_{i t}+\beta_{14} \ln I T_{i t}+ \\
& \beta_{15} \ln G D P_{e t}+\beta_{16} \ln B X_{e i t}
\end{aligned}
$$


$F D I_{\text {eit }}$ : foreign direct investment outflows from China to host economy $\mathrm{i}$ in year $\mathrm{t}$

$G D P_{i t}$ : gross domestic product of the host economy $\mathrm{i}$ in year $\mathrm{t}$

$P G D P_{i t:}$ per capita gross domestic product of the host economy $i$ in year $t$

$D_{e i}$ : the distance between China and the host economy $\mathrm{i}$

$B_{e i}$ : a dummy variable denoting border sharing between China and host economy $\mathrm{i}$

$C r_{i t}$ : the corruption index of host economy $\mathrm{i}$ in year $\mathrm{t}$

$L W_{i t}$ :the index for law and order of host economy $\mathrm{i}$ in year $\mathrm{t}$

$I M P+E X P_{i t:}$ total trade as a proportion of GDP in host economy $\mathrm{i}$ in year $\mathrm{t}$

$F T A_{\text {eit }}$ : a dummy variable denoting the existence of a free trade agreement

between China and host economy $\mathrm{i}$ in year $\mathrm{t}$

$K c_{i t}$ : capital control index in host economy $\mathrm{i}$ in year $\mathrm{t}$

$F S_{i t}$ : the share of food in total exports from host economy $\mathrm{i}$ to the world in year $\mathrm{t}$

FuS it : the share of fuel in total exports from host economy $\mathrm{i}$ to the world in year $\mathrm{t}$

$O S_{i t}$ : the share of ores and metals in total exports from host economy i to the world in year $t$

$R D_{i t}$ : research and development spending in host economy $\mathrm{i}$ in year $\mathrm{t}$

$I T_{\text {it }}$ : information technology expenditure in host economy $\mathrm{i}$ in year $\mathrm{t}$

$G D P_{e t}$ : GDP of China in year $\mathrm{t}$

$B X_{\text {eit }}$ : bilateral exchange rate between the currency of China and host economy $\mathrm{i}$ in year $\mathrm{t}$

Among several statistical conclusions, one interesting estimation result is that outward foreign direct investment from China is actually higher to more corrupt destinations (as measured by the corruption index of the host economy). A potential interpretation of this robust positive relationship between the amount of Chinese outward investment and the extent of corruption is that Chinese outward direct investments to the world, including those to Latin America is not solely based on business and commercial considerations. Much of the outward investments to Latin America are conducted by Chinese state-owned enterprises. Indeed, we can argue that such Chinese investment is influenced by both profit motives as well as noneconomic considerations such as buying good will from the Latin American countries. In other words, outward investment from China can be a part of China's foreign policy. The foreign policy-cum-economics motivation can also be seen in Chinese loans to the region. For example, more than half of the loan commitments from China went to one very close ally in the region-Venezuela. 
Figure 2

China's Imports from Latin America (\% Total)

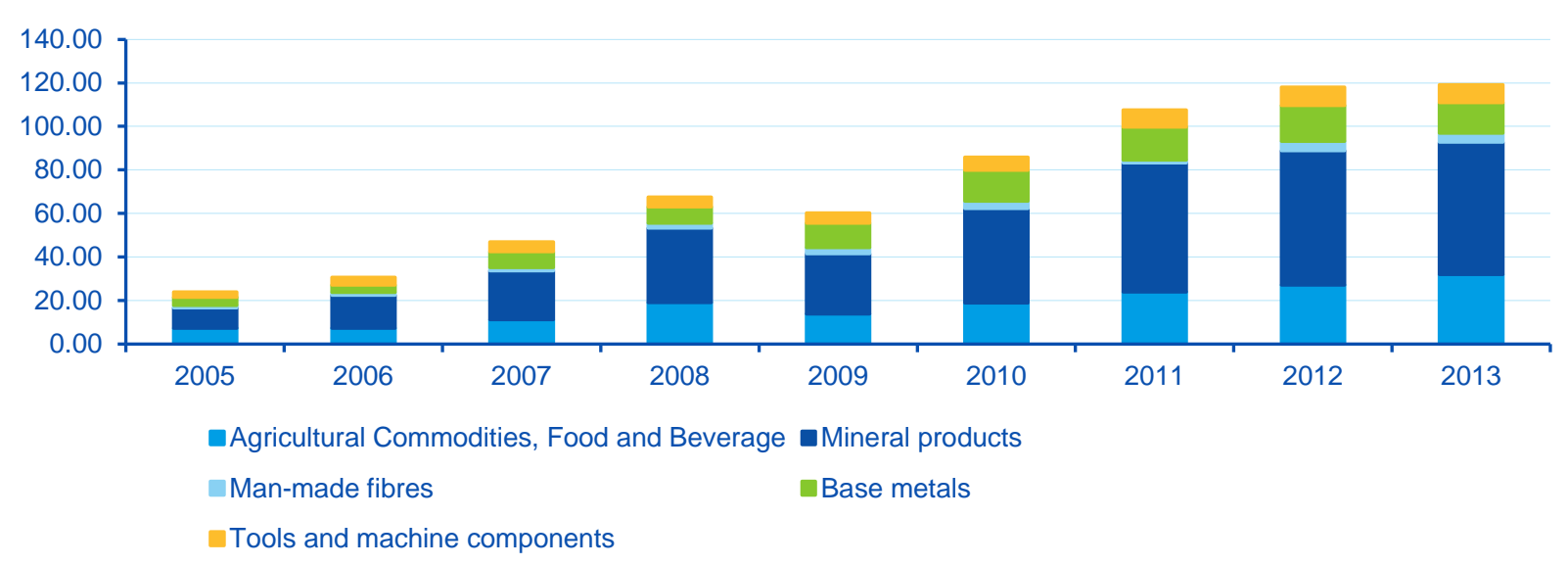

Source: UN COMTRADE 


\section{Reversed "Dutch Disease"}

As growth in China slows, the prospects of further increases in exports from Latin America to China dim. Prices of fuels and metals decline. The Chinese slowdown has two potential effects on Latin America economies.

One is a negative income effect. Commodity export revenues drop. The Latin American terms-of-trade (captured by the relative price index of commodities to that of manufactured goods) turn in favor of China. Real income and growth of Latin American countries that export minerals decrease. In 2014, iron ore export revenue from Brazil to China was US $\$ 12.3$ billion. However, this represented a decline of about $23 \%$ compared to 2013.

The second is the potential reversed concentration effect. During the decade-long commodity boom, Latin America was blessed with rising commodity prices but cursed with the "Dutch Disease". With the Dutch Disease, the resource sector expands, wages increase, the exchange rate rises but the manufacturing sector shrinks. Economic activities in Latin America are increasingly concentrated in production and export of commodities, particularly soybeans, copper and iron. According to Fung, Garcia-Herrero and Ospina (2013), the rise of China has worsened the dependence and concentration of Latin American exports in minerals and commodities. One important negative effect of such enhanced concentration is that potential economic development into more complex and sophisticated high-tech products can be stunted. As a contrast, South Korea's earlier big push into semiconductor manufacturing facilitated its rise in prominence first in plasma TV and laptops and more recently in smartphones.

Now Latin America is faced with a Dutch Disease reversal. Metal and food exports slow and exchange rates depreciate. With lower exchange rates and more sluggish wage growth, there is a potential possibility to expand non-commodity activities such as manufacturing. This potential "industrialization" however needs to be aided by judicious government policies, including building better physical infrastructure and further investment in schools to enhance human capital. Unfortunately it is also the time when government finances are hard to come by as export revenues deteriorate. 


\section{Co-operative Policies between China and Latin America}

To turn the slowdown of China into potential development opportunities for Latin America, the region needs to present win-win propositions to Chinese companies and government in order to entice China to help further diversify and grow their economies.

Latin America and China can have three areas of co-operation.:

First, Latin America should realize that China is very sensitive to perceived energy chokeholds. The region should further allow Chinese loans and direct investment. Through government bargaining, China should be enticed to bundle investments in resources and fuels with investment and loans in infrastructure building as well as investment in manufacturing.

Second, Latin America should enmesh China (and other Asian economies) in a joint China-Latin American supply chain. There is some recent evidence that China is exporting more electronic and telecom parts and components to the region. Indeed, much of Brazil's and Mexico's parts and components came from China, Hong Kong and Taiwan.

China should be encouraged to invest in factories to produce such parts in Latin America rather than just exporting. This initiative is related to the next move. China should be reminded of Latin American natural advantage in space and time, i.e. its geographic proximity and being in the same time zone as the United States, the largest consumer market in the world. A pan China-Latin American supply chain to serve the U.S. market will make business sense and be profitable to producers in both economies.

\section{Figure 3}

Sources of Mexican and Brazilian Imports of Parts and Components, 2010

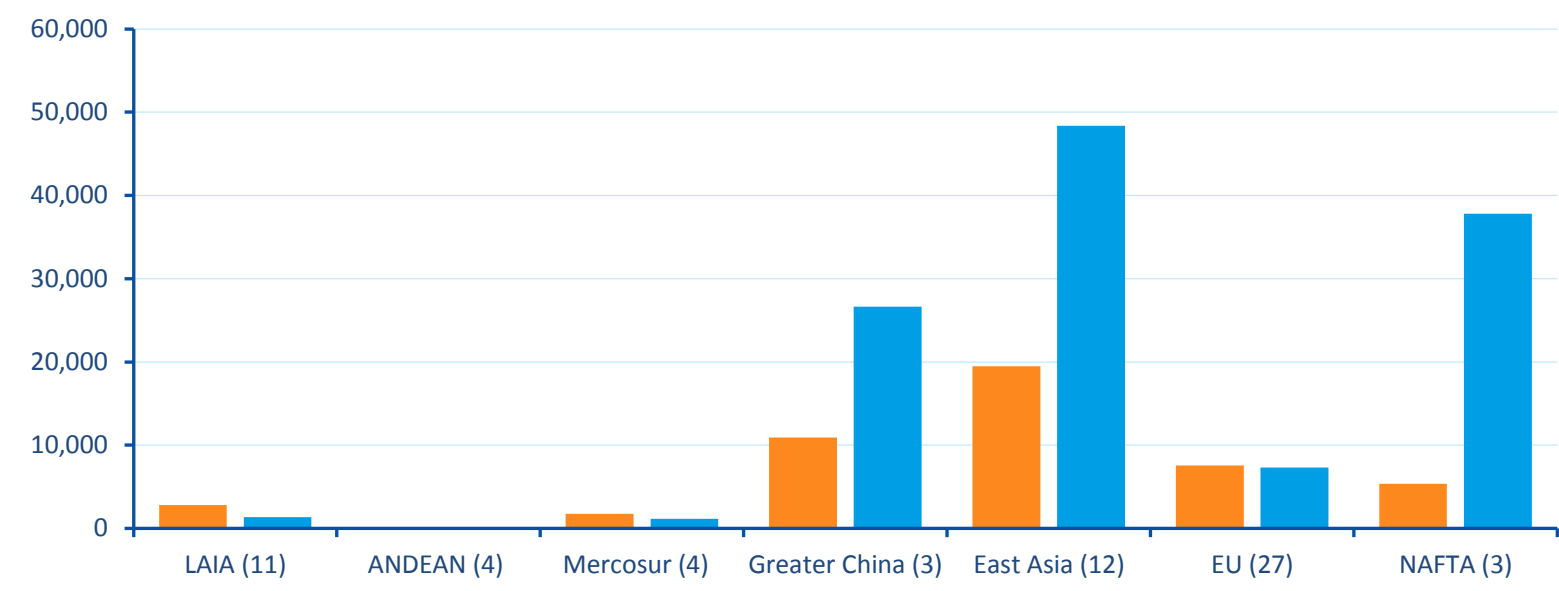

Brazil Mexico

Notes : The classifications of country groups are defined as follow:

ANDEAN (4) = Bolivia, Colombia, Ecuador and Peru

LAIA (11) = Argentina, Bolivia, Brazil, Chile, Colombia, Ecuador, Mexico, Paraguay, Peru, Uruguay and Venezuela.

Mercosur (4) = Argentina, Brazil, Paraguay and Uruguay.

Greater China (3) = China, Hong Kong, and Taiwan.

East Asia (12) = East Asia (9) plus Greater China (3).

Source: UN COMTRADE Statistic, Fung, Hwang and Seade (2015). 
Figure 4

Sources of Mexican and Brazilian Imports of Parts and Components, 2010

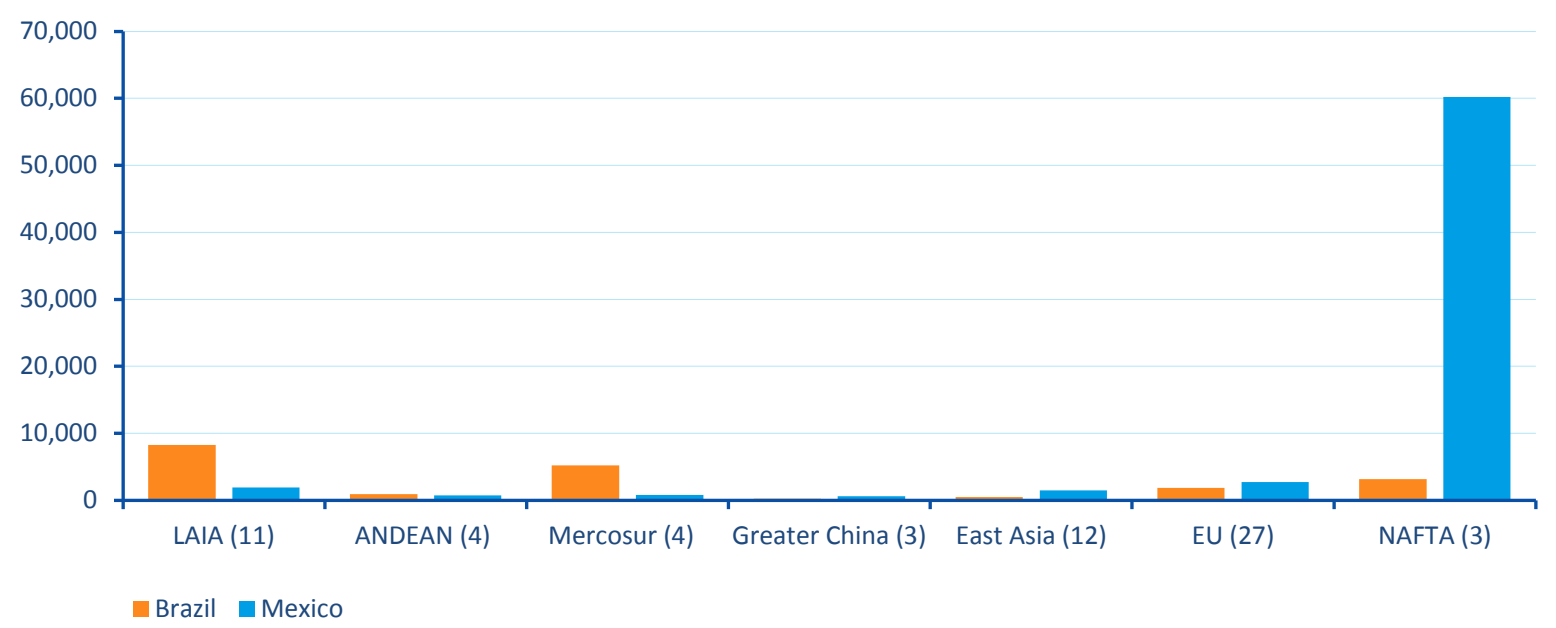

Notes : The classifications of country groups are defined as follow:

ANDEAN (4) = Bolivia, Colombia, Ecuador and Peru.

LAIA (11) = Argentina, Bolivia, Brazil, Chile, Colombia, Ecuador, Mexico, Paraguay, Peru, Uruguay and Venezuela

Mercosur (4) = Argentina, Brazil, Paraguay and Uruguay

Greater China $(3)=$ China, Hong Kong, and Taiwan.

East Asia (12) = East Asia (9) plus Greater China (3)

Source: UN COMTRADE Statistic, Fung, Hwang and Seade (2015) 


\section{References}

Estevadeordal, Antoni, Mauricio Mesquita Moreira, Christian Volpe Martincus and Juan S. Blyde, 2014, "Is India the Next Big Thing for Latin America? A Comparative Analysis of China's and India's Trade," in Fung, K.C. and Alicia Garcia-Herrero (eds), 2014, Sino-Latin American Economic Relations, Routledge Press, Paperback edition.

European Commission, Directorate General for Trade, 2015, "Statistics on China," Brussels, Belgium.

Deutsche Bank Research, Magdalena Forster, "China and Latin America," 2015.

Fung, K.C. and Alicia Garcia-Herrero, 2012, "Foreign Direct Investment Outflows from China and India," China Economic Policy Review, 2012.

Fung, K.C., Alicia Garcia-Herrero and Mario Nigrinis Ospina, 2013, "Latin American Commodity Export Concentration: Is There a China Effect?" BBVA Working Paper 2013.

Fung, K.C. and Alicia Garcia-Herrero (eds), 2014, Sino-Latin American Economic Relations, Routledge Press, Paperback edition. 


\section{Working Papers}

2015

15/18 Alicia Garcia-Herrero, K.C. Fung, Jesus Seade: Beyond Minerals: China-Latin American Trans-Pacific Supply Chain.

15/17 Alicia Garcia-Herrero, Le Xia, Carlos Casanova: Chinese outbound foreign direct investment: How much goes where after round-tripping and offshoring?

15/16 Diego José Torres Torres: Evaluando la capacidad predictiva del MIDAS para la Eurozona, Alemania, Francia, Italia y Portugal.

15/15 Alicia Garcia-Herrero, Eric Girardin, Arnoldo Lopez-Marmolejo: Mexico's monetary policy communication and money markets.

15/14 Saidé Salazar, Carlos Serrano, Alma Martínez, Arnulfo Rodríguez: Evaluation of the effects of the Free Trade Agreement between the European Union and Mexico on bilateral trade and investment.

15/13 Saidé Salazar, Carlos Serrano, Alma Martínez, Arnulfo Rodríguez: Evaluación de los efectos del Tratado de Libre Comercio entre la Unión Europea y México en el comercio bilateral y la inversión.

15/12 Alicia Garcia-Herrero, Eric Girardin \& Enestor Dos Santos: Follow what I do, and also what I say: Monetary policy impact on Brazil's financial markets.

15/12 Alicia Garcia-Herrero, Eric Girardin and Enestor Dos Santos: Follow what I do, and also what I say: Monetary policy impact on Brazil's financial markets.

15/11 Noelia Cámara, David Tuesta, Pablo Urbiola: Extendiendo el acceso al sistema financiero formal: el modelo de negocio de los corresponsales bancarios.

15/10 Noelia Cámara, David Tuesta, Pablo Urbiola: Extending access to the formal financial system: the banking correspondent business model.

15/09 Santiago Fernández de Lis, José Félix Izquierdo de la Cruz y Ana Rubio González: Determinantes del tipo de interés del crédito a empresas en la Eurozona.

15/08 Pau Rabanal and Juan F. Rubio-Ramírez: Can International Macroeconomic Models Explain Low Frequency Movements of Real Exchange Rates?.

15/07 Ángel de la Fuente y Rafael Doménech: El nivel educativo de la población en España y sus regiones: 1960-2011.

15/06 Máximo Camacho and Jaime Martínez-Martín: Monitoring the world business cycle.

15/05 Alicia García-Herrero and David Martínez Turégano: Financial inclusion, rather than size, is the key to tackling income inequality.

15/04 David Tuesta, Gloria Sorensen, Adriana Haring y Noelia Cámara: Inclusión financiera y sus determinantes: el caso argentino. 
15/03 David Tuesta, Gloria Sorensen, Adriana Haring y Noelia Cámara: Financial inclusion and its determinants: the case of Argentina.

15/02 Álvaro Ortiz Vidal-Abarca and Alfonso Ugarte Ruiz: Introducing a New Early Warning System Indicator (EWSI) of banking crises.

15/01 Alfonso Ugarte Ruiz: Understanding the dichotomy of financial development: credit deepening versus credit excess.

2014

14/32 María Abascal, Tatiana Alonso, Santiago Fernández de Lis, Wojciech A. Golecki: Una unión bancaria para Europa: haciendo de la necesidad virtud.

14/31 Daniel Aromí, Marcos Dal Bianco: Un análisis de los desequilibrios del tipo de cambio real argentino bajo cambios de régimen.

14/30 Ángel de la Fuente and Rafael Doménech: Educational Attainment in the OECD, 1960-2010. Updated series and a comparison with other sources.

14/29 Gonzalo de Cadenas-Santiago, Alicia García-Herrero and Álvaro Ortiz Vidal-Abarca: Monetary policy in the North and portfolio flows in the South.

14/28 Alfonso Arellano, Noelia Cámara and David Tuesta: The effect of self-confidence on financial literacy.

14/27 Alfonso Arellano, Noelia Cámara y David Tuesta: El efecto de la autoconfianza en el conocimiento financiero.

14/26 Noelia Cámara and David Tuesta: Measuring Financial Inclusion: A Multidimensional Index.

14/25 Ángel de la Fuente: La evolución de la financiación de las comunidades autónomas de régimen común, 2002-2012.

14/24 Jesús Fernández-Villaverde, Pablo Guerrón-Quintana, Juan F. Rubio-Ramírez: Estimating Dynamic Equilibrium Models with Stochastic Volatility.

14/23 Jaime Zurita: Análisis de la concentración y competencia en el sector bancario.

14/22 Ángel de la Fuente: La financiación de las comunidades autónomas de régimen común en 2012.

14/21 Leonardo Villar, David Forero: Escenarios de vulnerabilidad fiscal para la economía colombiana.

14/20 David Tuesta: La economía informal y las restricciones que impone sobre las cotizaciones al régimen de pensiones en América Latina.

14/19 David Tuesta: The informal economy and the constraints that it imposes on pension contributions in Latin America.

14/18 Santiago Fernández de Lis, María Abascal, Tatiana Alonso, Wojciech Golecki: A banking union for Europe: making virtue of necessity.

14/17 Angel de la Fuente: Las finanzas autonómicas en 2013 y entre 2003 y 2013.

14/16 Alicia Garcia-Herrero, Sumedh Deorukhkar: What explains India's surge in outward direct investment?

14/15 Ximena Peña, Carmen Hoyo, David Tuesta: Determinants of financial inclusion in Mexico based on the 2012 National Financial Inclusion Survey (ENIF). 
14/14 Ximena Peña, Carmen Hoyo, David Tuesta: Determinantes de la inclusión financiera en México a partir de la ENIF 2012.

14/13 Mónica Correa-López, Rafael Doménech: Does anti-competitive service sector regulation harm exporters? Evidence from manufacturing firms in Spain14/12

Jaime Zurita: La reforma del sector bancario español hasta la recuperación de los flujos de crédito.

14/11 Alicia García-Herrero, Enestor Dos Santos, Pablo Urbiola, Marcos Dal Bianco, Fernando Soto, Mauricio Hernandez, Arnulfo Rodríguez, Rosario Sánchez, Erikson Castro: Competitiveness in the Latin American manufacturing sector: trends and determinants.

14/10 Alicia García-Herrero, Enestor Dos Santos, Pablo Urbiola, Marcos Dal Bianco, Fernando Soto, Mauricio Hernandez, Arnulfo Rodríguez, Rosario Sánchez, Erikson Castro: Competitividad del sector manufacturero en América Latina: un análisis de las tendencias y determinantes recientes.

14/09 Noelia Cámara, Ximena Peña, David Tuesta: Factors that Matter for Financial Inclusion: Evidence from Peru.

14/08 Javier Alonso, Carmen Hoyo y David Tuesta: A model for the pension system in Mexico: diagnosis and recommendations.

14/07 Javier Alonso, Carmen Hoyo y David Tuesta: Un modelo para el sistema de pensiones en México: diagnóstico y recomendaciones.

14/06 Rodolfo Méndez-Marcano and José Pineda: Fiscal Sustainability and Economic Growth in Bolivia.

14/05 Rodolfo Méndez-Marcano: Technology, Employment, and the Oil-Countries' Business Cycle.

14/04 Santiago Fernández de Lis, María Claudia Llanes, Carlos López- Moctezuma, Juan Carlos Rojas and David Tuesta: Financial inclusion and the role of mobile banking in Colombia: developments and potential.

14/03 Rafael Doménech: Pensiones, bienestar y crecimiento económico.

14/02 Angel de la Fuente y José E. Boscá: Gasto educativo por regiones y niveles en 2010.

14/01 Santiago Fernández de Lis, María Claudia Llanes, Carlos López- Moctezuma, Juan Carlos Rojas y David Tuesta. Inclusión financiera y el papel de la banca móvil en Colombia: desarrollos y potencialidades. 
Click here to access the list of Working Papers published between 2009 and 2012

Click here to access the backlist of Working Papers:

Spanish and English

The analysis, opinions, and conclusions included in this document are the property of the author of the report and are not necessarily property of the BBVA Group.

BBVA Research's publications can be viewed on the following website: http://www.bbvaresearch.com

Contact Details:

BBVA Research

Paseo Castellana, 81 - 7th floor

28046 Madrid (Spain)

Tel.: +34 913746000 and +34 915377000

Fax: +34 913743025

bbvaresearch@bbva.com

www.bbvaresearch.com

bbvaresearch@bbva.com

www.bbvaresearch.com 